\title{
POZIOM AKTYWNOŚCI FIZYCZNEJ STUDENTÓW PIELEGGIIARSTWA WARSZAWSKIEGO UNIWERSYTETU MEDYCZNEGO
}

\section{THE LEVEL OF PHYSICAL ACTIVITY OF NURSING STUDENTS AT WARSAW MEDICAL UNIVERSITY}

\author{
Sylwia Sadłowska, Anna Zera, Andrzej Krupienicz \\ Zakład Podstaw Pielęgniarstwa \\ Warszawski Uniwersytet Medyczny
}

DOI: https://doi.org/10.20883/pielpol.2017.53

\section{STRESZCZENIE}

Wstęp. Aktywność fizyczna spełnia istotną funkcję w zakresie prewencji i profilaktyki wielu chorób. Stanowi jeden z najważniejszych determinantów prozdrowotnego stylu życia. Wpływa pozytywnie na wiele aspektów prawidłowego funkcjonowania organizmu.

Cel. Celem badań była ocena poziomu aktywności fizycznej studentów pielęgniarstwa Warszawskiego Uniwersytetu Medycznego.

Materiał i metody. W badaniu wzięło udział 136 studentów. Respondenci zostali poproszeni o dobrowolne wypełnienie autorskiej, anonimowej ankiety. Analizy statystycznej dokonano testem niezależności chi-kwadrat Pearsona. Hipotezę zerową odrzucono dla $p<0,05$.

Wyniki. Ponad połowa respondentów nie podejmowała jakiejkolwiek formy aktywności fizycznej. Dla 46,3\% ankietowanych brak czasu, dla 22,1\% lenistwo, a dla 19,9\% nauka były największymi barierami w podejmowaniu aktywności fizycznej. Studenci najchętniej wybierali ćwiczenia fitness, bieganie i spacery. Częstotliwość uprawiania sportu przekłada się na częstość odczuwania przez studentów dolegliwości - im mniejszy poziom aktywności fizycznej, tym częściej występują różne schorzenia. Wszyscy ankietowani uważają, że aktywność fizyczna i zdrowe odżywianie mają wpływ na zdrowie.

Wnioski.

1. Studenci pielęgniarstwa byli świadomi, że aktywność fizyczna oraz prawidłowy jadłospis mają wpływ na zdrowie.

2. Osoby nieuprawiające sportu częściej odczuwały różnego rodzaju dolegliwości.

3. Uprawianie ćwiczeń ruchowych było ograniczone przez brak czasu oraz niechęć do aktywności fizycznej.

4. Poziom aktywności fizycznej studentów pielęgniarstwa był niezadowalający.

SŁOWA KLUCZOWE: aktywność fizyczna, pielęgniarstwo, studenci.

\begin{abstract}
Introduction. Physical activity accomplishes a significant function in the field of prevention of many diseases. It is one of the most important determinants of a healthy lifestyle and has a positive effect on many aspects of proper functioning.

Aim. The aim of the research was to assess the level of physical activity in nursing students at Warsaw Medical University.

Material and methods. The study involved 136 students. The respondents were asked to complete the voluntary anonymous survey. Statistical analysis was performed by means of the Pearson's chi-square test. The null hypothesis was rejected at $\mathrm{p}<0.05$.

Results. Over a half of the respondents did not take any physical activity. $46.3 \%$ of the interviewees pointed to lack of time, $22.1 \%$ to indolence, and $19.9 \%$ to studying as the main reasons for not taking physical activity. Students most frequently choose the following type of sports: fitness exercises, running and walking. The frequency of taking up a sport is reflected in the frequency of occurring illnesses - the lower the level of physical activity, the more health problems occur. $100 \%$ of respondents believe that physical activity and healthy eating have an impact on health.

Conclusions.

1. Nursing students were aware that the physical activity and well-balanced menu had an impact on health.

2. Respondents not practicing sport often had various ailments.

3. Practicing physical exercises was limited by lack of time and aversion to sport.

4. The level of physical activity of nursing students was unsatisfactory.
\end{abstract}

KEYWORDS: physical activity, nursing, students. 


\section{Wstęp}

Ruch i aktywność fizyczna są nieodłącznymi elementami funkcjonowania człowieka i stanowią jedną z podstawowych potrzeb każdego z nas. Zaspokojenie tej potrzeby prowadzi do osiągnięcia dobrostanu fizycznego, psychicznego oraz społecznego, gwarantując tym samym optymalny rozwój na wszystkich płaszczyznach życia [1]. Podejmowanie aktywności fizycznej jest także doskonałym sposobem prewencji i profilaktyki wielu schorzeń, w tym chorób układu krążenia, osteoporozy, nadwagi i otyłości, a także zaburzeń natury psychicznej [2].

Styl życia młodzieży akademickiej cechuje się dużą różnorodnością, wynikającą z etapu edukacji, rozkładu zajęć, ilości nauki czy zasobów finansowych. Mimo iż studenci w większości przypadków posiadają wiedzę oraz są świadomi pozytywnego wpływu aktywności fizycznej na zdrowie, nierzadko nie podejmują wysiłku fizycznego ze względu na prowadzony tryb życia, uniemożliwiający im jego realizację [3].

\section{Cel badań}

Celem przeprowadzonych badań była ocena poziomu aktywności fizycznej studentów pielęgniarstwa Warszawskiego Uniwersytetu Medycznego.

\section{Materiał i metody}

W badaniu wzięli udział studenci studiów licencjackich na kierunku pielęgniarstwo Warszawskiego Uniwersytetu Medycznego. Grupa respondentów liczyła 136 osób - 132 kobiety i 4 mężczyzn.

Badanie ankietowe przeprowadzono w czasie od 30 listopada do 28 grudnia 2015 roku. Do zebrania danych zastosowano metodę sondażu diagnostycznego przeprowadzonego za pomoca anonimowego, autorskiego kwestionariusza ankiety składającego się z metryczki (płeć, miejsce pochodzenia, miejsce zamieszkania, rok studiów) oraz części zasadniczej ankiety zawierającej pytania dotyczące aktywności fizycznej i odżywiania: 11 pytań zamkniętych jednokrotnego wyboru i 5 pytań, w których można było udzielić maksymalnie 3 odpowiedzi. Sto ankiet zostało zebranych osobiście, podczas spotkań ze studentami, zaś 36 udostępniono na platformie Google Forms, gdzie respondenci udzielali odpowiedzi. Analizy statystycznej dokonano testem niezależności chi-kwadrat Pearsona. Hipotezę zerową odrzucono dla $p<0,05$.

\section{Wyniki}

Respondenci udzielili odpowiedzi na 16 pytań zawartych w kwestionariuszu ankiety, dotyczących głównie aktywności fizycznej.

Aktywność fizyczna dla $67,6 \%$ ankietowanych to metoda dbania o zdrowie, pozostali zaś wskazywali na: sposób poprawy kondycji fizycznej - 56,6\%, sposób na zmniejszenie masy ciała $-55,9 \%$, oraz metodę poprawy nastroju - 52,2\% (Rycina 1).

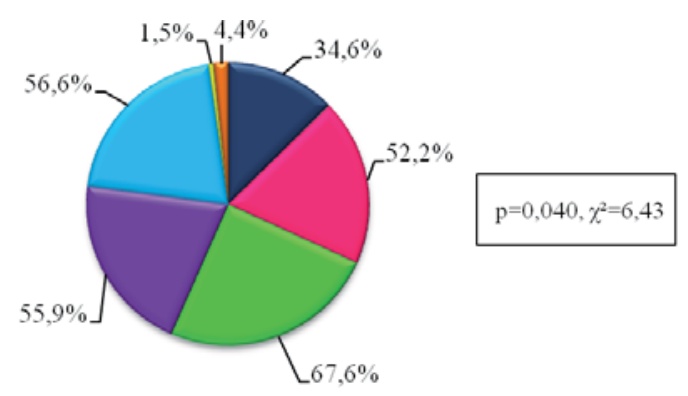

- Formą spẹdzania wolnego czasu/Form of spending a free time

- Sposobemna odreagowanie emocji, poprawę nastroju/ The way to stress out, lift one's spirits - Metoda dbania o zdrowie/Method to improve health

- Możliwościąna zmniejszenie masy ciala/The way to loose weight

- Sposobemna poprawę kondycji fizycznej/The way to improve physical condition

$\checkmark$ Drogą do poznawania nowych ludzi/The way to meet new people

a Aktywnośc fizyczna nie ma dla mnie znaczenia/Physical activity does not matter for me

p - prawdopodobieństwo testowe/probability value;

$\chi^{2}$ - wartość testu chi-kwadrat/value of the chi-square test

Rycina 1. Odpowiedzi respondentów na pytanie „Czym jest dla Ciebie aktywność fizyczna?"

Figure 1. Answers to the question: "What is physical activity for you?”

Źródło: opracowanie własne

Source: author's own analysis

Jeśli chodzi o częstość uprawiania sportu - przed rozpoczęciem studiów i w trakcie studiowania - wyraźnie widać, że odpowiedzi badanych różnią się. Można zaobserwować spadek częstotliwości uprawiania sportu w poszczególnych kategoriach oraz wzrost liczby osób niećwiczących w ogóle. Spośród 136 osób biorących udział w badaniu 66 zadeklarowało, że jest obecnie aktywnych ruchowo, zaś 70 osób nie podejmuje jakiejkolwiek aktywności fizycznej. Porównanie odpowiedzi udzielanych przez badanych zostało przedstawione na rycinach 2 i 3.

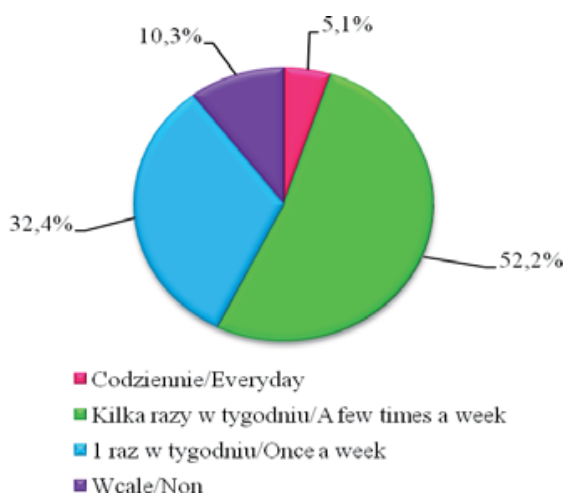

Rycina 2. Częstotliwość uprawiania sportu przed rozpoczęciem studiów na WUM

Figure 2. Frequency of practising sports before studying at the Warsaw Medical University

Źródło: opracowanie własne

Source: author's own analysis 


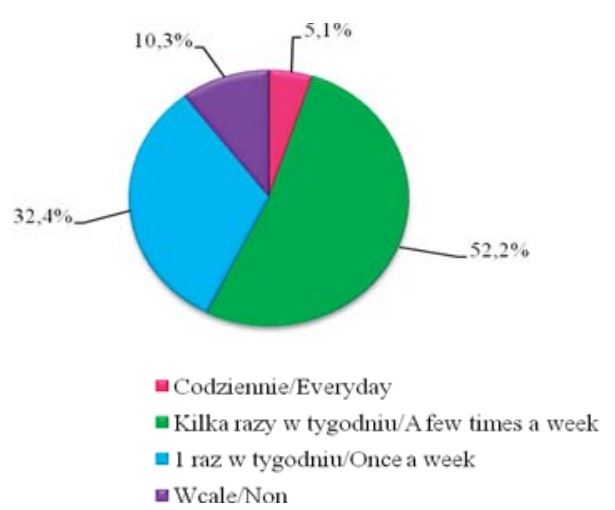

Rycina 3. Częstotliwość uprawiania sportu w trakcie studiów na WUM Figure 3. Frequency of practising sports during studying at the Warsaw Medical University

Źródło: opracowanie własne

Source: author's own analysis

Najczęściej podejmowaną formą aktywności fizycznej dla blisko $17 \%$ ankietowanych był fitness. Studenci wskazywali również na bieganie i spacery - po równo w $9,6 \%$ - jako ulubione formy ruchu.

Ze zdrowotnego punktu widzenia oraz biorąc pod uwage zalecenia towarzystw naukowych, optymalny czas podejmowanej aktywności fizycznej powinien wynosić minimum 30 minut, aby zaobserwować jej pozytywny wpływ na zdrowie. Blisko połowa ankietowanych - 47\% - udzieliła odpowiedzi wskazującej na ten okres.

Aktywność fizyczna wywołuje wiele pozytywnych skutków, w sferze zdrowia zarówno fizycznego, jak i psychicznego. Wybierając odpowiedzi, najwięcej ankietowanych wskazało lepsze samopoczucie - 33\%, oraz poprawę kondycji fizycznej - 23\% (Rycina 4).

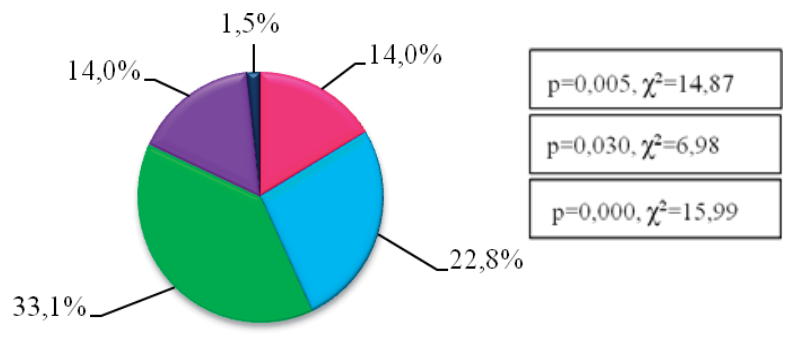

a Zmniejszenie masy ciala/Weight loss

- Poprawa kondycji fizycznej/Improvement of physical activity

- Lepsze samopoczucie/Better general sensation

• Poprawa wyglądu zewnętrznego/Improvement of superficies

a Poznanie nowych ludzi/Meeting new people

p-prawdopodobieństwo testowe/probability value

$\chi^{2}$ - wartość testu chi-kwadrat/value of the chi-square test

Rycina 4. Pozytywne skutki aktywności fizycznej

Figure 4. Positive results of physical activity

Źródło: opracowanie własne

Source: author's own analysis
Z drugiej strony, brak podejmowania regularnego wysiłku fizycznego prowadzi do wielu niekorzystnych zmian w organizmie, których objawem są różnego rodzaju dolegliwości. Studenci skarżyli się na bóle kręgosłupa - 33\%, obniżenie nastroju - 32\%, ból głowy - 30\%, w mniejszym stopniu przyrost masy ciała, bóle stawów i zaparcia. Ponadto wraz ze spadkiem częstości uprawiania sportu zwiększa się częstotliwość występowania schorzeń i odwrotnie (Tabela 1).

Tabela 1. Zależność między częstotliwością uprawiania sportu a częstotliwością odczuwania dolegliwości

Table 1. Relationship between the frequency of taking up a sport and the frequency of occurring illnesses

\begin{tabular}{|c|c|c|c|}
\hline $\begin{array}{l}\text { Częstotliwość } \\
\text { uprawiania } \\
\text { sportu/ } \\
\text { Frequency } \\
\text { of doing sports }\end{array}$ & $\begin{array}{c}\text { llość } \\
\text { odpowiedzi/ } \\
\text { Number } \\
\text { of answers }\end{array}$ & $\begin{array}{l}\text { Częstotliwość } \\
\text { odczuwania } \\
\text { dolegliwości/ } \\
\text { Frequency } \\
\text { of occurring } \\
\text { illnesses }\end{array}$ & $\begin{array}{c}\text { llość odpowiedzi/ } \\
\text { Number } \\
\text { of answers }\end{array}$ \\
\hline \multirow{4}{*}{$\begin{array}{l}\text { codziennie/ } \\
\text { everyday }\end{array}$} & \multirow{4}{*}{4} & $\begin{array}{l}\text { codziennie/ } \\
\text { everyday }\end{array}$ & 1 \\
\hline & & $\begin{array}{c}\text { kilka razy } \\
\text { w tygodniu/a few } \\
\text { times a week }\end{array}$ & 1 \\
\hline & & $\begin{array}{l}\text { raz w tygodniu/ } \\
\text { once a week }\end{array}$ & 2 \\
\hline & & wcale/non & 1 \\
\hline \multirow{4}{*}{$\begin{array}{l}\text { kilka razy w tygodniu/ } \\
\text { a few times a week }\end{array}$} & \multirow{4}{*}{25} & $\begin{array}{l}\text { codziennie/ } \\
\text { everyday }\end{array}$ & 1 \\
\hline & & $\begin{array}{c}\text { kilka razy } \\
\text { w tygodniu/a few } \\
\text { times a week }\end{array}$ & 5 \\
\hline & & $\begin{array}{l}\text { raz w tygodniu/ } \\
\text { once a week }\end{array}$ & 8 \\
\hline & & wcale/non & 1 \\
\hline \multirow{4}{*}{$\begin{array}{l}\text { raz w tygodniu/ } \\
\text { once a week }\end{array}$} & \multirow{4}{*}{37} & $\begin{array}{l}\text { codziennie/ } \\
\text { everyday }\end{array}$ & 5 \\
\hline & & $\begin{array}{c}\text { kilka razy } \\
\text { w tygodniu/a few } \\
\text { times a week }\end{array}$ & 11 \\
\hline & & $\begin{array}{l}\text { raz w tygodniu/ } \\
\text { once a week }\end{array}$ & 13 \\
\hline & & wcale/none & 8 \\
\hline \multirow{4}{*}{$\begin{array}{l}\text { wcale/ } \\
\text { none }\end{array}$} & \multirow{4}{*}{70} & $\begin{array}{l}\text { codziennie/ } \\
\text { everyday }\end{array}$ & 7 \\
\hline & & $\begin{array}{c}\text { kilka razy } \\
\text { w tygodniu/a few } \\
\text { times a week }\end{array}$ & 18 \\
\hline & & $\begin{array}{l}\text { raz w tygodniu/ } \\
\text { once a week }\end{array}$ & 28 \\
\hline & & wcale/none & 17 \\
\hline
\end{tabular}

Źródło: opracowanie własne

Source: author's own analysis

Ponad połowa ankietowanych, która zadeklarowała brak uprawiania jakiejkolwiek formy sportu, jako główne powody takiej decyzji wskazywała brak czasu - 46\%, lenistwo - 22\%, konieczność nauki - 20\%, oraz inne, wśród których można wymienić brak pieniędzy, złą 
kondycję fizyczną, stan zdrowia oraz brak akceptacji ze strony rodziny i znajomych.

Zarówno jeśli chodzi o pozytywny wpływ aktywności fizycznej, jak i zdrowego odżywiania się na zdrowie, ankietowani stwierdzili zgodnie w 100\%, że w obu przypadkach istnieje takowe oddziaływanie.

\section{Dyskusja}

Towarzystwa naukowe ds. zdrowia oraz WHO systematycznie publikują zalecenia dotyczące optymalnego poziomu aktywności fizycznej w profilaktyce i prewencji wielu chorób oraz utrzymaniu zdrowia [4-6]. W lokalnej społeczności to studenci pielęgniarstwa, których przyszła praca pielęgniarki/pielęgniarza będzie polegała nie tylko na opiece nad człowiekiem chorym, lecz także na promocji zdrowia i edukacji zdrowotnej, powinni być świadomi wpływu określonych zachowań zdrowotnych - głównie aktywności fizycznej i prawidłowego odżywiania - na stan zdrowia. Jako przyszli specjaliści w dziedzinie zdrowia powinni wiedzieć, jak prowadzić odpowiedni styl życia, aby je wzmacniać. Badanie wykazało jednogłośnie, że zarówno aktywność fizyczna, jak i regularne posiłki oraz zdrowy, urozmaicony jadłospis mają wpływ na zdrowie, co potwierdzają także inne badania prowadzone wśród studentów kierunków medycznych i nie tylko. Wg autorki badań przeprowadzonych w Kielcach na grupie 132 studentów różnych kierunków studiów w tym także pielęgniarstwa - 97,73\% badanych uważa, że aktywność fizyczna ma pozytywny wpływ na zdrowie [7] - nieznacznie mniej niż w wynikach przedstawionych badań, które wykazały 100\% pozytywnych odpowiedzi. Również nieco mniej ankietowanych - prawie 92\% w badaniu Zarzecznej-Baran i Wojdak-Haasy [8] uznało, że aktywność fizyczna wpływa korzystnie na zdrowie, zaś 96\% zadeklarowało znajomość pozytywnego wpływu zdrowego odżywiania na zdrowie oraz znajomość zasad żywienia - ten aspekt w wynikach przedstawionych badań wynosił także 100\%.

Uprawianie sportu dla respondentów w badaniach własnych było przed wszystkim metodą dbania o zdrowie - $67,6 \%$, a także w dużej mierze sposobem na poprawę kondycji fizycznej - 56,6\%, możliwością zmniejszenia masy ciała - 55,9\%, oraz sposobem na odreagowanie emocji, lepsze samopoczucie - 52,2\%. Otrzymane wyniki są wyższe niż u innych autorów, aczkolwiek porównywalne, wymieniane są podobne motywy. Markiewcz-Górka zaobserwowała, że najważniejsze motywy podejmowania aktywności fizycznej to: chęć uzyskania zgrabnej sylwetki, dbanie o zdrowie, poprawa kondycji, zaś ponad połowa ankietowanych - 51,1\% - wskazała dobre samopoczucie fizyczne i psychiczne [9]. Wyniki prezentowanych badań wskazują, iż motywy podejmowania aktywności fizycznej przekładają się również na pozytywne skutki uprawia- nia sportu. Wśród ankietowanych 52,2\% wskazało, że aktywność fizyczna jest dla nich sposobem na poprawę nastroju, odreagowanie emocji, a w rezultacie 33\% badanych zadeklarowało lepsze samopoczucie jako efekt wykonywania ćwiczeń. W badanej grupie 56,6\% respondentów uznało, że aktywność fizyczna jest sposobem na poprawę kondycji fizycznej i 22,8\% badanych wskazało, że faktycznie zaobserwowali lepszą sprawność fizyczną. Częstotliwość wykonywania ćwiczeń, porównując okres przed rozpoczęciem studiów z czasem studiów, zmniejszyła się znacznie, zaś wzrosła liczba osób niepodejmujących aktywności w ogóle. Fakt ten znalazł potwierdzenie w wynikach badań własnych. Wiąże się to ze zmianą trybu życia w związku ze studiowaniem na kierunku pielęgniarstwo. Ćwiczenia, zajęcia praktyczne i wykłady wypełniają praktycznie cały dzień studentów. Nie mają oni czasu na jakąkolwiek aktywność fizyczną sensu stricto, poza przemieszczaniem się między placówkami, w których odbywają się zajęcia.

Zalecenia dotyczące czasu trwania aktywności fizycznej w celu osiągnięcia pożądanych efektów zdrowotnych oscylują w granicach 30-45 minut, 4-5 razy w tygodniu. W badaniach Dębskiej najmniej osób zadeklarowało uprawianie sportu > 60 minut dziennie. Pozostali wskazywali na czas od 30 do 60 minut lub mniej niż pół godziny [7]. U Zarzecznej-Baran i Wojdak-Haasy najwięcej odpowiedzi dotyczyło ogólnej systematyczności w wykonywaniu ćwiczeń oraz systemu 3×30×130, czyli uprawiania sportu 3 razy w tygodniu, po $30 \mathrm{mi}-$ nut, tak aby tętno wzrosło do 130 uderzeń/minutę [8]. Z przeprowadzonego sondażu wynika, iż ponad połowa studentów - 51,2\% - nie ćwiczy w ogóle, zaś 27\% ćwiczy kilka razy w tygodniu, a zaledwie 18\% - raz w tygodniu, głównie od 15 do 30 minut. Świadczy to o niskim poziomie aktywności fizycznej ankietowanych, biorąc pod uwagę ogół uczestniczących w badaniu. Również w badaniu Nieradko oraz Borzęckiego studenci medycyny Lubelskiej Akademii Medycznej w przeważającej części nie podejmowali jakiejkolwiek aktywności fizycznej [10]. Podobnie u Stasiołek i Jegier, które prowadziły badania wśród studentów kierunku lekarskiego Łódzkiej Akademii Medycznej, stwierdzono niski poziom aktywności fizycznej badanych [11]. Można w takim razie zaryzykować stwierdzenie, że kierunek studiów - w tym przypadku medyczny - wpływa znacząco na poziom aktywności fizycznej studentów. Studiowanie na uczelni medycznej wiąże się z niskim poziomem aktywności fizycznej.

Dębska w swoich badaniach zaobserwowała trzy najbardziej popularne formy aktywności fizycznej: bieganie, spacery oraz gimnastykę [7]. Wyniki tych badań pokrywają się z uzyskanymi w prezentowanym badaniu własnym - tu również były to najczęściej podejmowane rodzaje wysiłku fizycznego wśród ankietowanych. Każ- 
dy posiada własną, najbardziej preferowaną dyscyplinę sportu.

W badaniu Sochockiej i Wojtyłko ankietowani wskazali na brak czasu $(56,8 \%)$ jako główny powód niepodejmowania aktywności fizycznej [12]. Również w naszym badaniu ta odpowiedź została podawana najczęściej - 46,3\%. Także w badaniach Markiewicz-Górki i wsp. oraz Zarzecznej-Baran i Wojdak-Haasy respondenci wskazywali najczęściej tę odpowiedź [8, 9]. Wiele osób nie ćwiczy po prostu z lenistwa - 22,1\%, oraz ze względu na naukę - 19,9\%. Te wartości również są porównywalne z wynikami badań innych autorek [8, 12].

Hipokinezja - niedostateczny poziom aktywności fizycznej - niesie za sobą wiele niepożądanych następstw. Studenci zapytani o częstotliwość występowania różnego rodzaju dolegliwości blisko w 75\% przypadków wskazali na ich odczuwanie - codziennie, kilka razy w tygodniu lub raz w tygodniu, co ma związek z poziomem aktywności fizycznej. Im rzadziej podejmowane ćwiczenia, tym częściej występują dolegliwości. Najczęściej ankietowani wskazywali występowanie bólu kręgosłupa - 33\%.

W badaniach Stefanowicz i Kloca studenci pielęgniarstwa w 52,5\% zadeklarowali systematyczne uprawianie sportu. Wśród badanych 76,19\% odczuwało bóle kręgosłupa, a $23,81 \%$ nie odczuwało bólu. Pozostali - 47,5\% badanych - uważali swoją aktywność fizyczną za niedostateczną i 73,68\% z nich wskazywało na ból w dolnym odcinku kręgosłupa [13]. Również w innym badaniu 34\% studentów zadeklarowało odczuwanie bólu kręgosłupa, a u $20 \%$ bóle występowały czasami, czyli więcej niż 50\% badanych zmagało się bólami kręgosłupa [14].

Studenci pielęgniarstwa ze względu na specyfikę swojego zawodu powinni w sposób szczególny przejawiać zachowania prozdrowotne służące zachowaniu i umacnianiu zdrowia, być wzorem do naśladowania, czyli prowadzić „zdrowy styl życia”. Literatura podaje, że aby wzmacniać zdrowie, należy podejmować działania w kierunku zmiany nieprawidłowych nawyków żywieniowych, zwiększania świadomości społeczeństwa na temat wpływu odżywiania na zdrowie, profilaktyki nałogów oraz zwiększania poziomu aktywności fizycznej [15].

\section{Wnioski}

1. Studenci pielęgniarstwa byli świadomi, że aktywność fizyczna oraz zdrowy, prawidłowo zbilansowany jadłospis mają wpływ na zdrowie.

2. Wiedza studentów na temat wpływu aktywności fizycznej i odżywiania na zdrowie nie przekładała się na ich zachowania prozdrowotne.

3. Ponad połowa ankietowanych nie podejmowała jakiejkolwiek aktywności ruchowej.

4. Osoby nieuprawiające sportu częściej odczuwały różnego rodzaju dolegliwości.

5. Uprawianie ćwiczeń ruchowych przez studentów było ograniczone przez brak czasu oraz niechęć do aktywności fizycznej.
6. Poziom aktywności fizycznej studentów pielęgniarstwa był niezadowalający.

\section{Piśmiennictwo}

1. Bielski J. Metodyka wychowania fizycznego i zdrowotnego. Kraków: Impuls; 2005. 43, 64, 96, 548-551, 554.

2. Ambroziak M. Wysiłek fizyczny a układ krążenia. Podstawy fizjologiczne i genetyczne. Wpływ na ryzyko chorób sercowo-naczyniowych. Post Nauk Med. 2008; 10: 653-659.

3. Winiarska-Mieczan A, Dymek T. Ocena aktywności fizycznej wśród młodzieży akademickiej lubelskich uczelni. Med Sport. 2009; 2(6): 125-131.

4. Woynarowska B. Edukacja zdrowotna. Podręcznik akademicki. Warszawa: PWN; 2008. 19, 52, 57, 294.

5. Jegier A. Trening zdrowotny. W: Adach Z, Brzenczek-Owczarzak W, Celejowa I, Górski J (red.). Fizjologia wysiłku i treningu fizycznego. Warszawa: PZWL; 2012. 235-243.

6. American Heart Assocication Recommendations for Physical Activity in Adults, http://www.heart.org/HEARTORG/ Healthy-Living/PhysicalActivity/FitnessBasics/American-Heart-Association-Recommendations-for-PhysicalActivity-in Adults_UCM_307976_Article.jsp (data dostępu: 17.03.2016).

7. Dębska M. Stan aktywności fizycznej studentów. Pol Prz Nauk Zdr. 2014; 2 (39): 138-142.

8. Zarzeczna-Baran M, Wojdak-Haasa E. Wiedza studentów akademii medycznej w Gdańsku o niektórych elementach stylu życia. Probl Hig Epidemiol. 2007; 88: 55-59.

9. Markiewicz-Górka I, Korneluk J, Pirogowicz I. Aktywność fizyczna oraz wiedza studentów Akademii Medycznej we Wrocławiu na temat jej roli w profilaktyce chorób - badania ankietowe. Fam Med Primary Care Rev. 2011; 13: 436-439.

10. Borzęcki A, Nieradko B. Aktywność fizyczna, higiena snu i zagospodarowanie czasu w ciągu dnia przez studentów Wydziału Lekarskiego Akademii Medycznej w Lublinie. Ann UMCS. Sec D. 2003; 58(1): 358-362.

11. Jegier A, Stasiołek $D$. Aktywność ruchowa studentów medycyny. Now Lek. 2003; 72(2): 140-142.

12. Sochocka L, Wojtyłko A. Aktywność fizyczna studentów studiów stacjonarnych kierunków medycznych i niemedycznych. Med Środow. 2013; 16(2): 53-58.

13. Posłuszna M. Edukacja zdrowotna we współczesnej szkole - program prozdrowotny. Probl Piel. 2010; 18(2): 226-231.

14. Kloc W, Stefanowicz A. Rozpowszechnienie bólu krzyża wśród studentów. Pol Ann Med. 2009; 16(1): 28-41.

15. Krajewska-Kułak E, Sieradzki M, Van Damme-Ostapowicz K. Ocena występowania zespołów bólowych dolnego odcinka kręgosłupa w populacji studentów kierunku fizjoterapia. Probl Hig Epidemiol. 2013; 94(3): 451-458.

Artykuł przyjęty do redakcji: 09.11.2016

Artykuł przyjęty do publikacji: 25.01.2017

Źródło finansowania: Praca nie jest finansowana z żadnego źródła. Konflikt interesów: Autorzy deklarują brak konfliktu interesów.
Adres do korespondencji:
Sylwia Sadłowska
Karlusin 72
08-300 Sokołów Podlaski
tel. kom.: 509412738
e-mail: s_sylwia@wp.pl
Zakład Podstaw Pielęgniarstwa
Warszawski Uniwersytet Medyczny 